Gender and Queer Perspectives on Brexit, edited by Moira Dustin, Nuno Ferreira, Susan Millns (Palgrave 2018)

Hege Skjeie, Professor, Department of Political Science, University of Oslo

Cathrine Holst, Professor, Department of Sociology and Human Geography, University of Oslo

Mari Teigen, Research Professor, Institute for Social Research, Oslo.

\title{
Splendid Isolation?
}

\section{On How a Non-Member Is Affected By - And Affects - EU Gender Equality Policy}

\begin{abstract}
Although not a member of the European Union (EU), Norway is deeply affected by European integration, not least owing to its participation, since 1994, in the European Economic Area (EEA) Agreement which made Norway a full participant in EU's internal market. Norway's commitments to the EEA also apply to the area of gender equality policy. Yet, a comprehensive public inquiry report (NOU 2012:2) on the consequences of Norway's affiliation status concluded that EEA commitments and other EU agreements had limited impact on the scope and content of actual policy making in the gender area not least because Norwegian regulatory schemes quite easily could fulfil/ expand on EU “minimum standards".

This chapter will critically examine this claim through a discussion of EU influences on four core gender equality policy themes: antidiscrimination law, work-life balance, gender mainstreaming, and gender quotas for corporate boards. Applying the familiar distinction between top down and bottom up Europeanisation the chapter also draws on recent research by the authors on the uses of EU in Norwegian expert recommendations on gender equality policy. The chapter concludes with a re-assessment of how affiliation status has been shown to be relevant to policy development in this area.
\end{abstract}




\section{Introduction: Europeanisation Through EEA Affiliation}

Historically, the Nordic region has been viewed as both a strong and a unified agent of gender equality advocacy. Nordic countries have comparatively strong equality records and Nordic policy innovations travel the world. Different Nordic polities have, through their own initiative, produced innovations such as low threshold monitoring of equality legislation (1970s), gender mainstreaming of public policies (1980s), bans on the purchase of sex (1990s), and corporate board quotas (2000s) (Skjeie, Holst and Teigen 2017). The 'Nordicness' of gender equality policy is still most famously recognised in the welfare state policies to promote work-family balance through extensive parental leave and public child care schemes (Esping-Andersen 2009; Leira 2012; Walby 2009).The different Nordic countries have however chosen quite different European Union tracks. Denmark has been a member of the EUfor 45 years, since 1973, and Danish gender equality policy was thus Europeanised much earlier than their Nordic neighbours' (Borchorst and Rolandsen Augustin 2018). In popular referendums both Sweden and Finland chose to join the EU in 1994, while a majority in Norway and Iceland voted to remain outside. But Iceland and Norway have both participated, since 1994, in the European Economic Area (EEA) Agreement which makes the countries full participants in the EU's internal market.

The EU affects Norwegian hard law through the EEA and also through the 73 - as of 2017 additional agreements between the EU and Norway (see Eriksen and Fossum 2015; Holst and Stie 2016). Furthermore, policies and governance have been Europeanised more softly through the increased coordination among the different levels of public administration in Europe, including the Norwegian ministries, agencies, and offices; transnational social movements and civil society actors; and through Norwegian participation in border-crossing knowledge-sharing communities, such as the European Commission's expert groups, or when national inquiry commissions are influenced by Europeanised value sets, problem definitions, and conceptions of best practices (Skjeie, Holst and Teigen 2017, see also Egeberg and Trondal 2015).

The commitments as part to the EEA apply directly to the area of gender equality policy (NOU 2012: 2, in particular 17.5). Yet, as we know, gender equality policy varies considerably in the EU area, including among member states. Unsurprisingly, in Norway there has been substantive hard law harmonisation as a result of EU regulations and court decisions and most of the central EU anti-discrimination directives have been transposed into 
Norwegian legislation as part of the EEA Agreement, but also as a result of voluntary adoption. Changes in Norwegian equality policy due to EEA commitments are, however, not fully visible in public gender equality debate. Instead, they appear mainly as important reform themes within bureaucratic and epistemic communities (see for instance Kraglund 2018), but even here the attention given EU integration processes and adaptations vary (Holst 2018).

In this chapter we address EU influence on changes in Norwegian gender equality policy since the mid 1990s. Our discussion is inspired by approaches in Europeanisation theory that emphasise the filtering role of nation-specific meaning frames (Börzel and Risse 2003), but also how European norms may constitute important resources for national agenda-setting (Jacquot and Woll 2003). In particular, we pay attention to the notion of discursive uses of the EU, i.e. the situations where national policy actors frame agendas with reference to EU standards and norms. Finally, we look not only at how EU laws and policies have been incorporated into the Norwegian political system - the 'import side', but also at how Norwegian or Nordic arrangements affect the EU area and EU initiatives - the 'export' side. We thus strive to combine top-down and bottom-up perspectives on EU influence. To illustrate how discursive uses of EU may play out in actual policy formation processes we rely on recent studies, but also use our own experience as members of a governmental appointed expert commission - The Gender + Equality Commission - which in 2010-2012 was mandated to investigate Norwegian gender equality policies, paying particular attention to the intersection of gender, ethnicity, and class. ${ }^{1}$ Four specific areas of equality policy are discussed. We first address EU influence on Norwegian policy traditions with regard to equality legislation, work-life balance and gender mainstreaming, before we turn to the question of Norwegian influence on EU attempts to regulate the gender composition of corporate boards. This choice of themes obviously leaves other core gender equality areas unexamined, such as violence against women, gender perspectives on health, or broad equal pay policies - policy areas which all are important in the public debate on gender equality.

In 2012, a comprehensive public inquiry report (NOU 2012:2) on the consequences of Norway's affiliation status concluded that EEA commitments and other EU agreements had had limited impact on the scope and content of actual policy making in the gender area, not least because Norwegian regulatory schemes were assessed to easily meet EU "minimum

\footnotetext{
1 "Gender + equality" is a term borrowed from political science's gender equality research: see summary and sources for the European research project QUING, led by Mieke Verloo, http://www.quing.eu/index.php?option=com_content\&task=view\&id=17\&Itemid=34 visited 10-28-14
} 
standards". As our discussion shows this is an overly superficial notion of EU influence on Norwegian gender equality policy. It treats "minimum standards" as standards that are easily achieved when in reality, as we argue EU regulatory standards present quite profound challenges to dominant, mainly social democratic, convictions about how gender equality should be sought.

\section{Equality Legislation - European Judicialisation}

The dominant gender equality policy tradition in Norway prioritises, first, building familyoriented welfare state policies through publically financed childcare facilities and generous parental leave schemes, and second, promoting gender balance norms through quotas and various forms of preferential treatment (Skjeie and Teigen 2012, NOU 2012:15, chapter 2). This priority is largely built on the country's social democratic heritage: The Labour Party's main gender equality policy has been building and expanding gender equality-friendly welfare state arrangements aimed at improving the balance of work and family life and thus helping to secure women's economic independence through labour market integration (NOU 12:15, cf. Borchorst et al 2012). Norway was however an "early achiever" in terms of legislating against gender based discrimination: As early as 1978 a comprehensive law on gender equality was passed by parliament. The law covered "all areas of society" although with a series of limitations to this general scope, in particular related to the competencies of the low threshold system set up to monitor the law. The legislative initiative established the world's first Gender Equality Ombud and Gender Equality Tribunal as a low threshold mechanism. The low threshold system was however only able to rule on discrimination complaints, deciding whether or not discrimination occurred. The parties to the complaint were then expected to acknowledge the ruling and agree among themselves on what, if any, form of compensation was appropriate. While individual discrimination cases also could be brought before the courts, the low threshold instantly became the regular route. In spite of severe limitations to the low threshold competencies, very few discrimination cases have thus been decided by regular courts in Norway (cf. NOU 2011:18).

From the outset, the Norwegian gender equality legislation combined bans on direct and indirect discrimination with regulations that relate to proactive advancement of gender equality (cf. later section on gender mainstreaming). Proactive duties for state agencies and public and private employers form a central part of current equality legislation. However, due to a lack of proper enforcement, the proactive duties mainly function as symbolic legal 
statements. In comparison to broad welfare state initiatives on public childcare and parental leave schemes, individual and systemic discrimination have received scant attention within the social democratic gender equality order. It is mainly processes of Europeanisation in the Norwegian context that has contributed to widening protection against discrimination (NOU 2012:2, NOU 2011:18, Skjeie, Holst and Teigen 2017).

The EEA agreement covers all EU gender equality directives. Norwegian gender equality law has most notably been changed to incorporate more efficient legal remedies to address discrimination, such as the principles of strict liability and shared burden of proof. Limitations put on wage comparisons in the equal pay regulation have also been modified to comply with EU law. Moreover, important new rules on protection against harassment and sexual harassment and against retribution are directly tied to national implementation of EU regulations (Skjeie and Teigen 2003, Hedlund 2008, Kraglund 2018). However, there is still much leeway in adoptation at national level. For instance, while low threshold monitoring applies to the general ban on harassment, the sexual harassment ban is not enforced through the low threshold system but only by the regular courts.

It is only on the issue of preferential treatment that interpretation of Norwegian gender equality law has been limited, rather than extended as a consequence of interpretation of EU law. The institutionalisation of quota arrangements is a hallmark of Norwegian gender equality policy. Quotas applying to the nomination procedures of political parties have been sequentially adopted since the late 1970s; to the appointment of public boards and commissions since the 1980s and 1990s, and - most famously - to the boards of private and public corporations since the early 2000s (for an overview see Skjeie and Teigen 2012). Various forms of preferential treatment policies have long been applied in both admission to higher education and in hiring within such institutions, as well as within public administration in general. Yet, in 2003, a case before the EFTA court decided against the University of Oslo's targeted earmarking of specific postdoctoral positions. The earmarking arrangement was found to violate the EEA agreement as it reserved the positions exclusively for women (NOU 2012:2, 498) ${ }^{2}$ and the further interpretation of this decision by Norwegian authorities put new limitations on a hitherto favoured preferential treatment tool of Norwegian gender equality policy (NOU 2012:2).

\footnotetext{
${ }^{2}$ http://www.eftacourt.int/uploads/tx_nvcases/1_02_RH_EN.pdf
} 
Over the past two decades, there has been a significant broadening of legal protection against discrimination in Europe. This development has also contributed to profound change in Norwegian equality legislation. Implementing new EU directives, member states' equality legislation has expanded to cover not only gender, but also racial or ethnic origin, religion or belief, disability, age and sexual orientation - the EU "six strands" policy base (Krizsan, Skjeie and Squires 2012). This has been accompanied by an increasingly complex set of institutional arrangements to address inequalities ${ }^{3}$ and new politics of equality have emerged within a multiple discrimination framework. However, EU directives on non-discrimination take a 'ground-by-ground' approach; the need to protect against multiple discrimination has mainly been addressed in recitals and soft law supplements to formal legal texts. In contrast to, for instance, CEDAW-based approaches, the specificities of intersectional discrimination are rarely noted and multiple equality initiatives are still largely contained within a strict nondiscrimination framework, with positive duty programs or gender mainstreaming policies tending to remain one-dimensional (Skjeie 2015).

The first Norwegian moves to legislate against discrimination on the basis of race, ethnicity and religion were made in the late 1990s through amendments to the Work Environment Act; this, however, was foremost as a domestic follow up of the ILO convention 111. International pressures in particular contributed to the establishment of a Centre for Combatting Ethnic Discrimination (Borchorst et al 2012:66), an agency which however, had no legal enforcement competencies. Comprehensive equality laws aiming to cover all of the EU directives' protected strands were enacted from 2005 onward, mainly modelled on the Gender Equality Act and this law's general scope ("all areas of society”, cf. above). For sexual orientation, gender identity and gender expression comprehensive legislation was not passed until 2013. Age received similar broad protection only when this ground was included in a new unified equality and antidiscrimination law in 2017 (Lovvedtak 118 (2016-2017). The new equality legislation also contains a clause which prohibits multiple discrimination ("combinations of grounds" in §6).When trying to pinpoint the most important consequences of EU law for protection against discrimination, the public inquiry report analysing Norway's affiliation status concluded that "age" had benefited the most. Discrimination on the basis of age is also the strand which is most frequently tried in court (NOU 2012:2:498-499) .

\footnotetext{
${ }^{3}$ For a comprehensive mapping of equality institutions in Europe, see for instance Andrea Krizsan, Hege Skjeie and Judith Squires (eds): Institutionalising Intersectionality: The changing nature of European Equality Regimes. Basingstoke: Palgrave, 2012
} 
The comprehensive set of EU antidiscrimination directives has clearly led to improved protection for vulnerable groups in Norway. Their transposition in member states has meant a spread in the number of low threshold anti-discrimination bodies, previously found in just a few countries (Krizsan, Skjeie, and Squires 2012: 211). Norway has, however, maintained a low threshold monitoring system in the form of Ombud and Tribunal since the enactment of the Gender Equality Law in the late 1970s. With the adoption of the new equality laws this arrangement was simply extended to cover the newly protected strands. This meant that the significant limitations built into the low threshold enforcement and monitoring system also applied to the new equality legislation. In general terms, these limitations, in combination with the lack of public legal aid in discrimination cases before the courts, bring the whole issue of access to justice to the fore, as explored in the following paragraphs. It was only in 2017 changes were made to contain competence for the Equality Tribunal to grant compensation to victims of employment related discrimination. The authors of this chapter all partook in the initiative which finally secured this reform, which we will explain more closely. From 2010 to 2012 we were part of a government-appointed expert commission mandated to investigate gender equality status and policies, paying particular attention to the intersection of gender, ethnicity, and class. ${ }^{4}$ The efforts of the Norwegian Gender+ Equality Commission to draw attention to the lack of effective sanctions within the Norwegian system strategically tapped into European Union developments to strengthen protection against discrimination, in what is conceptually characterised as "discursive use of EU" (see Kraglund 2018, cf. Lombardo and Forest 2012). As outlined, the Norwegian low threshold system was only able to rule on discrimination complaints, deciding whether or not discrimination occurred. The parties to the complaint were then expected to acknowledge the ruling and agree among themselves on what, if any, form of compensation was appropriate. If they could not agree, the only option for victims of discrimination was bringing the case before the regular courts. No public legal aid is available for bringing discrimination cases to court. The Commission described the entire development of anti-discrimination legislation in Norway in the early 2000s as mainly EU-inspired and the issue of 'effective sanctions' was then placed within this context, motivationally combining references to EU requirements on "efficient" and "proportional" sanctions with CEDAW obligations and the Paris principles on access to justice (NOU 2011:18, particularly 10.3 -10.4).

\footnotetext{
${ }^{4}$ The Commission delivered two reports: NOU 2011:18, Struktur for likestilling (Structure for equality) and NOU 2012:15 Politikk for likestilling (Policy for equality).
} 
The Commission thus pointed to the obvious political inconsistency of combining strong substantive legislation with weak enforcement mechanisms and lack of legal aid, and deplored the lack of reform in this respect - that is, the blatant neglect of legal efficiency during nearly 40 years of expanding equality legislation. In terms of remedies there was, however, no common EU model available, simply because none exists (Kraglund 2018; Wladasch 2015). The Commission chose a Nordic path and borrowed a relevant model from Denmark and the competencies of the Danish equality tribunal to rule on compensation; an alternative model was borrowed from the competencies of the Swedish Equality Ombud to try discrimination cases in court. The Commission also stressed that the ban on sexual harassment should be included within the scope of low threshold competencies (NOU 2011:18).

The centre-left cabinet then in office were, however, not interested in legal reform. It was not until a governmental change of guard to a predominantly rightist cabinet in 2013 that reform of the low threshold sanction system was finally carried through - however, leaving sexual harassment to be handled in its old and obviously ineffective way whereby few cases are tried in the regular courts. ${ }^{5}$ Reflecting on the reasons why judicial efficiency has been neglected in the Norwegian context, we point mainly to a strong policy tradition which tends to treat gender equality as an "evolving process" rather than a judicially enforceable right (Skjeie, Holst and Teigen 2017). The general lack of concern expressed about access to justice in the Norwegian context is clearly due to embedded views on the inappropriateness of judicialisation of gender equality policy (for Danish parallels see Borchorst and Rolandsen Augustin 2018). Thus judicialisation is probably the key benefit that gender equality agency in Norway has received from EU affiliation.

\section{Work-life balance: family policy with a Nordic signature}

Work-life balance has long been flagged as a central goal in EU's gender equality strategies. Yet, social policies are the responsibility of member states, putting strains on EU policymaking in this area (Kantola 2010). The European Commission's 2015 withdrawal of the proposed maternity leave directive illustrates how current procedures allow unfriendly

\footnotetext{
${ }^{5}$ It is only the global \#metoo movement, and a consequent series of harassment scandals within the major Norwegian political parties, that has moved establishment thinking towards a new solution in this respect. However, as of February 2018, it is still unclear how a low threshold system might be applied [specify applied to what?].
} 
member states to block progressive initiatives, but the EU's limited engagement also reflects a lack of prioritisation, and, recently, austerity pressures (Kantola \& Lombardo 2017).

Nevertheless, over time, the EU's equal treatment requirements have facilitated women's inclusion and equal standing in the labour market, and the EU's equal pay legislation in particular has contributed massively to increasing women's wages (van der Vleuten 2007). The Union has moreover stimulated the diffusion of norms and best practice, soft policy coordination and the development of common benchmark mechanisms in the area of worklife balance (see for example Hubert et al. 2011).

Nordic family policy has been perceived as an essential Nordic model trademark and as looming far above EU standards (for overviews, see Leira 2002, 2012, Ellingsæter 2014, Skevik 2003). Hence, one might expect to see Norwegian policies in this area exported to both member states and EU initiatives, rather than seeing EU approaches and measures imported to Norway. And indeed, manifest traces of Europeanisation in Norway are few. Over time, a range of family- and parent-friendly services and benefits have been institutionalised in Norway, but the EU seems to have played a rather marginal role. The development of publicly subsidised kindergartens, day-care centers and out-of-school care had been a priority from the 1990s onwards if not earlier, and Norway is currently regarded as having full kindergarten coverage. Paid parental leave has been gradually extended and is now 49 weeks at 100 percent coverage (or 59 weeks with 80 percent coverage). Ten weeks are reserved for the mother, 10 weeks for the father, while the remaining weeks are a shared period. ${ }^{6}$ In addition, there are rights for parents to unpaid long-term leave to care for newborns and small children, the right to paid leave of absence for nursing mothers, and the right to paid leave to care for sick children. A set of special benefits for single parents are in place. Finally, there is universal child benefit for anyone supporting children under the age of 18 , and also tax benefits for families, and a cash-for-care benefit for parents with children that do not attend state-sponsored nurseries. However, studies of the history of Norwegian family policy show few, if any of these inspirations coming from the EU, or indeed EU set limitations (Vollset 2011).

Norwegian fertility rates are relatively high and commonly regarded as an outcome of this package of work-life policies. Worries about decreasing fertility are thus not pronounced.

\footnotetext{
${ }^{6}$ However, in accordance with proposal from the Gender+ Equality Commission, from 2018 on the parental leave will be split in three equal shares, $1 / 3$ reserved for the mother, $1 / 3$ for the father, and $1 / 3$ as a shared period
} 
Norway has also no explicit fertility policy, which contrasts with the increased focus on fertility in many European countries, but also at EU-level (Neyer 2017). Reproductive rights are firmly protected, and The Norwegian Abortion Act (1978) is relatively liberal: abortion is available on demand until the end of the $12^{\text {th }}$ week of pregnancy. Norway was also a pioneer when it comes to codifying children's rights, with its early progressive Children Act (1915) that obliged both parents to provide for extra-marital children, and entitled single mothers with financial support. An Ombud for Children, the first of its kind, was established in 1981 (Skevik 2003).

This policy field then is generally and quite reasonably conceived of as largely homegrown; it bears the signature of Nordic social democracy and was first and foremost developed here. However, policies and approaches have not been controversy-free, and contemporary debates on family policy in Norway, although grounded in the national context, cover concerns and issues familiar from elsewhere that are also on the EU agenda (European Commission 2016). One such issue is how to strike the right balance between ensuring universal welfare rights and providing incentives to increase employment rates for all groups of women. In Norway, a concrete expression of this concern is the vivid debate over the cash-for-care scheme and its implications for women's inclusion in the labor market and integration of minority women in particular (Ellingsæter 2014). Another controversy occurred around paternity leave, which proponents see as a decisive step towards reduced gender gaps in the work-family area, whereas critics worry about families' freedom of choice. A third debate concerns the relationship between services and benefits in the family policy infrastructure, where a 2017 proposal from a public commission on family policy (NOU 2017: 6) to replace the universal child benefit with a means-tested benefit in combination with free kindergarten for all children, received much attention, including during that year's election campaign (Holst 2018).

Moreover, there is a trend towards greater Europeanisation even in the area of family policy (Holst 2018). Yet, typically for this policy domain, European integration is primarily regarded as creating new difficulties and policy challenges. Illustratively, the mandate of the above mentioned family policy commission, asks for a review of existing policies in light of the problem of so-called "benefit export" said to arise from the free movement and equal treatment principles of the EEA agreement. The commission focuses in its response on the child benefit and the cash-for-care benefit - to what extent do working parents in Norway 
send off these benefits to children residing in other EEA area countries? It concludes, however, that public spending on such "export" of benefits is still very limited.

Furthermore, the European Court of Justice's 2015 decision in the Maistrellis case has raised the question of whether equal treatment requirements are properly ensured in cases of parental leave schemes where fathers' leave rights are conditional upon mothers' employment. As the Norwegian scheme includes such a clause, the Maistrellis case has triggered an exchange between the EFTA Surveillance Authority (ESA) and the Norwegian government about whether Norwegian parental leave arrangements are in accordance with EU law. The Norwegian government claims that it is, while ESA has remained skeptic over this interpretation. Some feminist law scholars have supported ESA's approach (see for example Ketscher 2018). Yet, the family policy commission, while recognising the disagreement, decided in the end to be loyal to the government's interpretation on this point, stating that it is "outside its mandate" to position itself in legal disagreements in absence of a court decision on the Norwegian scheme specifically (NOU 2017: 6, 10.1.1).

This is a reminder of how the strength and shape of Europeanisation depends on actors' interpretations and strategies (Radaelli \& Pasquier 2006, Kraglund 2016), and that the judicialisation of Norwegian gender equality policy triggered by the EU is not an automatic, top-down process. Interestingly, the approach of the family policy commission differs from that of another commission close to the work-life area, namely the equal pay commission (NOU 2008: 6). In accordance with the strategies of previous commissions on the issue of equal pay, the 2008 report made reference to EU gender equality directives, court decisions and supportive legal scholarship to question limitations put on wage comparisons by Norwegian equal pay legislation (Holst 2018).

\section{Gender mainstreaming - a widespread policy failure}

Gender mainstreaming has been the official strategy of gender equality policy in Norway for forty years, that is to say, since the adoption of the Gender Equality Act in 1978. The mission statement of the Act was "to promote equality and in particular the position of women" (§1a). To fulfill this aim it was stated that "all public authorities shall facilitate for gender equality on all areas of responsibility" ( $\$ 1 b)$. Since the late 1990s, gender mainstreaming strategy also corresponded with change in EU's approach to equal opportunities from a narrow focus on 
equal treatment in the workplace to an acceptance of positive action and institutionalisation of gender sensitive norms and practices in public policy more broadly (Hafner-Burton and Pollack 2002, Rees 2005). Gender mainstreaming simply implies that all policies should address relevant gender issues and through this promote gender equality. In the Nordic context, mainstreaming has had a particularly high standing in Swedish gender equality policy, and it has been argued that Scandinavian impulses were important for the EUs adoption of the gender mainstreaming approach (Pollack and Hafner-Burton 2000), in particular tied to Sweden and Finland's entrance to the European Union in 1995.

The development of Swedish gender equality policy undoubtedly shows a particular strong tradition of institutionalisation of equality policies, and through this a structure for the implementation of gender mainstreaming (Daly 2005, Sainsbury and Bergquist 2009, Freidenvall 2018). However, implementation studies tend to show varied degrees of success (Callerstig 2014, Ahrens and Callerstig 2017, Freidenvall 2018). Freidenvall, for instance, finds that processes of Europeanisation and national knowledge production have dynamically developed Swedish gender equality policies but that European influences have been stronger in the development and expansion of discrimination policies than for gender mainstreaming policy (Freidenvall 2018). It seems fair to state that in terms of policy traditions, Swedish gender mainstreaming is "exported", not "imported", and in this sense it tends to remain a nationally instigated policy endeavor.

EU-based implementation of gender mainstreaming is still far from being a strategic success in Norway. In their analysis of the implementation of both gender mainstreaming and environmental policy integration in the European Commission, Hafner-Burton and Pollack (2009) conclude that such soft policies fail in changing the behavior of European Commission officials. Hence they argue that hard incentive policies are needed to give such gender perspectives any chance of competing with concerns about economic competitiveness that enjoy "principle priority” in contemporary EU policymaking (Hafner-Burton and Pollack 2009).

Nevertheless, the EU formal prioritization of gender mainstreaming resonates in Norwegian law. As far back as the preparatory work for the Gender Equality Act in 1978, integration of a gender equality perspective across all policy fields was argued as necessary for effective gender equality policy, and was consequently anchored within the activity duty in the mission 
statement of the Gender Equality Act. ${ }^{7}$ The activity duty was strengthened as part of a comprehensive revision of the Gender Equality Act in 2002, where the duty to make active, targeted and systematic efforts to promote gender equality was extended to all employers (including in the private sector) and to social partners in the labour market, who then became obliged to improve gender equality in their businesses and in their field of responsibility. ${ }^{8}$ In its reasoning for the revision, the Government drew a connection between the activity duty in the Gender Equality Act and the EU's gender mainstreaming policy. The strengthening of the EU's gender equality policy, and the introduction of gender mainstreaming following the Amsterdam treaty entering into force in 1997 was explicitly linked with the proposal to strengthen the activity duty. EU developments were discursively used to underpin new national legislation in this respect: While the government argued that EU mainstreaming initiatives did not directly affect the EEA agreement at this point in time, they added that this might be the case later. ${ }^{9}$ Otherwise, the government was vague about the relevance of EU/EEA concerns in relation to Norway's gender mainstreaming policy.

Gender mainstreaming is, of course, a particularly demanding approach because of its requirement that all central actors analyse the gender aspects of any policy process (cf. Pollack and Hafner-Burton 2000). Gender mainstreaming in Norway presupposes that equality efforts should be integrated into the daily work of all authorities, in all decisionmaking processes, and by all relevant actors. However, the Gender + Equality Commission's investigation into the implementation of mainstreaming activities in national, regional and local public administration made it abundantly clear that such activities were scarce (NOU 2011: 18). Although gender mainstreaming is anchored in the activity duty of the Gender Equality Act and in government instructions for policy preparation, where an obligation to conduct gender-sensitive consequence analysis has existed since the mid-2000s, there has been no monitoring of such written obligations. No comprehensive gender budgeting is in place; no systematic assessment of equality consequences in legislation and policy formulation has been carried out; equality work has mainly been geared towards temporality

\footnotetext{
${ }^{7}$ The Activity Duty in the Gender Equality Act was included in 1978 obliging all public authorities to make active, targeted and systematic efforts to promote gender equality. In 2008 the Activity Duty was extended to include ethnicity, religion and disability

${ }^{8}$ Ot. prp. nr. 77 (2000-2001), s. 25-33.

https://www.regjeringen.no/contentassets/d495493b08ef4fdc9f46412c524f2466/no/pdfa/otp2000200100770 00dddpdfa.pdf

${ }^{9}$ Ot. prp. nr. 77 (2000-2001), s. 25-33.

https://www.regjeringen.no/contentassets/d495493b08ef4fdc9f46412c524f2466/no/pdfa/otp2000200100770 $\underline{\text { oodddpdfa.pdf }}$
} 
in the form of various "action plans" on different areas; and there has been little equality expertise available to guide equality eager authorities etc (NOU 2011:18).

The overall lack of good practices with regard to mainstreaming is clearly related to the lack of proper enforcement mechanisms in Norwegian equality legislation. The Commission consequently argued for the importance of anchoring oversight authority and building an institutional structure to secure the implementation of gender equality policy. To further this cause, it first explained the overarching relevance of the Beijing Platform of Action to equality mainstreaming efforts, and then extensively outlined the Swedish governments' large-scale investment in mainstreaming activities over the past decade. No mention was made of the Amsterdam Treaty's mainstreaming obligations, and EU-based mainstreaming efforts were generally not discussed. The Commission needed to show best practices and the EU level had little to offer in this respect. However, this effort to increase the institutional capabilities of gender + equality promotion in the Norwegian context did not succeed as the political will to anchor authority over legal obligations to do gender mainstreaming was not present.

\section{Gender Quotas for Corporate Boards - a Norwegian innovation with European repercussions}

Promoting gender balance norms through quotas and various forms for preferential treatment is a dominant tradition in Norwegian gender equality policy (Skjeie and Teigen 2012, Teigen 2015). Since 1981, as part of a revision of the Gender Equality Act, the Act has stated that both genders should be represented on state appointed commissions, councils and boards, and since 1988 the Act specified the demand for gender parity to at least 40 percent of each gender in state appointed commissions, etc.; the same regulation was applied to municipal commissions etc. in the Municipal Act since 1992. ${ }^{10}$ Other Nordic countries have passed similar legislation, yet in line with its comparatively strong quota tradition, Norway was also the first country to propose (1999), adopt (2003), and implement (2008) corporate board gender quotas $(\mathrm{CBQ}) .{ }^{11}$ The formulation of this regulation was modelled on the regulation covering the gender composition of public commissions in the Gender Equality Act. However, it was not made a part of the equality legislation. Instead, CBQ became part of

\footnotetext{
${ }^{10}$ The gender composition of commissions etc. appointed by the government has been regulated since 1970s, and finally included in legislation in 1981, as part of the Gender Equality Act (Solhøy 1999).

${ }^{11}$ However with the exception that Israel from 1999 the statuary requirement that all publicly traded companies should have at least one woman on the company board (Hughes et al. 2017).
} 
Companies legislation. Interestingly, a main reason for situating CBQ in Companies legislation was to ensure strict enforcement of the regulation, so that similarly strict sanctions would apply to this regulation as to other company regulations. The sanction system specifies that a company that does not have a legal board, despite several warnings (followed by fines) allowing it to correct the matter, will be subject to forced dissolution. The Norwegian Business register is designed to ensure compliance with the law. CBQ thus forms a clear exception to the general trend for weak enforcement mechanisms in equality legislation that we have identified in this chapter.

The CBQ reform was a highly controversial legal regulation. The "women in management" debate, particularly high on the public agenda in the 1990's Norway, as well as in most of the industrialised world, is an important part of the context explaining Norway's introduction of CBQ. This debate hit Norway particularly hard because it interfered with the country's national self-image of itself as particularly successful on issues of gender equality. In Norway, as in the other Nordic countries, a discrepancy exists between a relatively balanced representation of men and women in political decision-making on the one hand, and strong vertical gender segregation in the labor market, and especially in the business sector (Teigen \& Wängnerud 2009, Niskanen 2011).

Through the introduction of corporate board quotas, Norway became an initiator of the wave of corporate board quota requirements that have since swept across Europe and other parts of the world (Fagan et al. 2012, Teigen 2012, Terjesen et al. 2015, Hughes et al. 2017). Since the early 2000s, the issue of gender quotas on corporate boards has been much discussed by governments, parties and parliaments in a wide range of countries. In an impressive burst of policy diffusion, parliaments in Spain (2007), Iceland (2009), France (2011), Belgium (2011), the Netherlands (2011), Italy (2011) and Germany (2016), have introduced gender quotas for corporate boards. Other countries have introduced voluntary measures, such as Austria, Denmark, Finland, and United Kingdom (Mensi-Klarbach 2017). Gender balance on corporate boards is generally progressing in Europe, although significant progress is restricted to countries that have introduced legislative measures. ${ }^{12}$

In tandem with the policy diffusion of CBQ in several European countries, regulation of gender balance on corporate boards was placed on the agenda of the European Commission after a new commission entered into power in 2010 (Barosso II), and with Viviane Reding as

\footnotetext{
${ }^{12}$ http://www.womenlobby.org/Cracks-in-the-glass-ceiling-or-just-a-trick-of-the-light
} 
Vice-President and Commissioner of Justice, Fundamental Rights and Citizenship. A lengthy policy process in the European Commission finally resulted in the proposal for a directive on the regulation of the gender balance of boards of large corporations: Proposal for a Directive of the European Parliament and of the Council on improving the gender balance among nonexecutive directors of companies listed on stock exchanges and related measures. The proposition was considered controversial by some key actors, but was passed by the European Parliament, however, a blocking minority in the Council of Ministers have prevented the proposition to be passed (Seierstad et al. 2017, Lépinard and Rubin 2018, forthc., Inderhaug 2018).

Inderhaug (2018) shows how Norwegian experiences played a central role in the directive process in EU. Norwegian politicians, bureaucrats and experts were invited to share their experiences and analysis in meetings, hearings and conferences. The case of Norway was central in the reasoning leading to the European Commission directive proposal, and in the debate leading to the vote in favor of the proposal in the European parliament. In the European Council of Ministers debate, however, where the proposal was turned down, the Norwegian example was less central. In the Council, representation reflects the size of the population of each member country, hence Germany's opposition to the directive and the strong voice of Germany Chancellor Angela Merkel on this matter became weighty factors explaining why the directive was not adopted (Inderhaug 2018). ${ }^{13}$

Norwegian experiences have clearly played a significant role in placing the CBQ issue on the European agenda, both in individual European countries and at the supranational level in the EU. However, as pointed out by Inderhaug (2018), Norwegian experiences played a less prominent role in the European Council of Ministers than in other parts of the EU system. While Norwegian policy influence managed to change the EU agenda, the directive process in EU is still pending. In this respect it is tempting to suggest that absence from the table matters, and as a result, Norwegian influence on EU policymaking will be modest at best.

\section{Conclusion: Judicialisation With Leeway}

Broadly speaking, Norway has adopted the European Union's increasingly ambitious equality agenda from the early 2000s, when this agenda was significantly broadened through the Amsterdam Treaty. The Nordic countries are commonly portrayed as in the vanguard of

\footnotetext{
${ }^{13}$ Article from the European Women's Lobby on the European Commission's Directive on Women on Boards: https://www.womenlobby.org/The-European-Commission-s-Directive-on-Women-on-Boards
} 
gender equality policy innovation, and, as shown in this chapter, Norway can also boast a comparatively long tradition of gender equality advocacy. However, it seems clear that EU regulatory standards have presented a profound challenge to the dominant, mainly social democratic, legacy of policy convictions about how gender equality should be pursued. Bluntly stated, this legacy prioritises the development of a welfare state ensuring public childcare and parental leave to promote women's labour market participation, rather than seeking effective remedies to discrimination, or promoting educational and workplace equality. Instead of treating such policies as complementary the first have been prioritised over the latter in the social democratic order, so that judicialisation of gender equality claims has been minimised and welfare state infrastructure maximised. The comprehensive set of antidiscrimination directives has led to improved protection for vulnerable groups in Norway while generous arrangements to promote work-family balance have, so far, remained largely immune to EU influence. Gender mainstreaming policy is still as inefficient in Norway as it is in EU at large, and the exceptional Norwegian board quota model has not yet succeeded in making a distinct mark at European level.

While present day Norwegian equality law owes much to the strict standards of EU law, this development has not been uncontroversial as it challenges a systemic unwillingness to ensure the effectiveness of gender equality legislation. Anxiety about judicialisation in the Norwegian context is primarily expressed as a domestic concern driven by the increasing influence of supranational law on domestic law and policymaking. It resonates across Europe not least as a result of the enforcement of the European Convention on Human Rights by the European Court of Human Rights and through EU member states' obligations to comply with the rulings of the Court of Justice of the EU. In Norway, attempts to broaden the scope of directly enforceable human rights through 'full text' incorporation of international conventions have for example been met with hesitance and avoidance strategies by every government since the early 2000s. The dynamic interpretive style of international human rights bodies is argued in particular to skew the balance (cf. Skjeie, Holst and Teigen 2017).

Interestingly, "judicialisation" is sometimes fiercely contested, while on other occasions it goes almost unnoticed, despite significant implications. Controversy has for instance been harsh over several rulings of the European Court of Human Rights. EEA obligations have also spurred controversy, recently among unions who worry over deregulation, increased competition and lowered social standards (Holst \& Stie 2016). However, in the gender equality area the EU and EU agreements are still regarded as having limited impact. As this 
chapter has shown, this is somewhat of a misconception, even if this view is supported by the 2012 official report on the relationship between EU and Norway.

The European Court of Justice's 2015 decision in the Maistrellis case, however, holds the potential to change this state of affairs, as the case has direct relevance for present-day Norwegian parental leave regulations. How this EU challenge will evolve is still unclear. It could represent a blow to the very heart of national self-determination over what is commonly regarded as core gender equality policy; the welfare state infrastructure which primarily aims to promote women's labour market participation. Fathers' independent rights to parental leave have in this context - so far - clearly been subordinated.

Generally, the judicialisation of Norwegian gender equality policy triggered by the EU is still not an automatic, top-down process. There is much leeway for national initiative in the development of policy and a large scope for strategic uses of EU. Our discussion has shown how EU is discursively used - or strategically non-used - to promote the views already held by national constituencies of gender equality-friendly actors. In this sense, in this policy area Norway's ties to EU has so far mainly constituted a win-win situation: EU influence has unequivocally contributed to judicialisation many would regard as progressive, but arguably not at the expense of the women- and family-friendly welfare state. 


\section{References}

Ahrens, Petra and Anne-Charlott Callerstig (2017): "The European Social Fund and the Institutionalisation of Gender Mainstreaming in Sweden and Germany". In: Heather Mc Rae and Elaine Weiner (eds.), Towards Gendering Institutionalism. Rowman \& Littlefield International, ISBN 9781783489961, 69-100.

Borchorst, Anette, Lenita Freidenvall, Johanna Kantola, Liza Reisel, and Mari Teigen (2012): "Institutionalizing Intersectionality in the Nordic Countries? Anti-Discrimination and Equality in Denmark, Finland, Norway, and Sweden.” In Institutionalizing Intersectionality? The Changing Nature of European Equality Regimes, edited by Andrea Kriszan, Hege Skjeie, and Judith Squires, 59-88. Basingstoke: Palgrave Macmillan.

Borchorst, Anette, and Lise Rolandsen Augustin (2018): “Køn, ligestilling og retliggjørelse: Europeiseringen av dansk likgestillingspolitik”. In: Cathrine Holst, Hege Skjeie and Mari Teigen (eds.), Europeisering av nordisk likestillingspolitikk. Oslo: Gyldendal Akademisk.

Börzel, Tanja, and Thomas Risse (2003). "Conceptualizing the Domestic Impact of Europe”. In: The Politics of Europeanization, edited by Kevin Featherstone and Claudio M. Radaelli, 57-80. Oxford: Oxford University Press.

Callerstig, Anne-Charlott (2014): Making Equality Work: Ambiguities, Conflict and Change Agents in the implementation of equality policies in public sector organizations. $\mathrm{PhD}$ thesis, Linköping University

Daly, Mary (2005): “Gender Mainstreaming in Theory and Practice”. Social Politics 12 (3), 433-450. https://doi.org/10.1093/sp/jxi023

Egeberg, Morten and Jarle Trondal. 2015. "National Administrative Sovereignty: Under Pressure.” In The European Union's Non-Members, edited by Erik Oddvar Eriksen and John Erik Fossum, 173-88. London: Routledge.

Ellingsæter, Anne-Lise (2014): "Nordic Earner-Carer Models - Why Stability and Instability?” Journal of Social Policy, 43(3) pp. 555-574.

Eriksen, Erik Oddvar and John Erik, Fossum, eds. (2015): The European Union's NonMembers. London: Routledge.

Esping-Andersen, Gösta (2009): The Incomplete Revolution. Cambridge: Polity Press. European Commission (2016) Strategic Engagement for Gender Equality 2016-2019. European Commission: Justice, Consumers and Gender Equality. 
Fagan, Colette, Maria C. Gonzalez Menendez, and Silvia Gomez Ansón (2012): Women on Corporate Boards and in Top Management. European Trends and Policy. London: Palgrave.

Freidenvall, Lenita (2018). “Institutionaliseringen av svensk jämställdhet: lager-på-lagerprocesser och fokusförflyttning”. I: Cathrine Holst, Hege Skjeie og Mari Teigen (red.), Europeisering av nordisk likestillingspolitikk. Oslo: Gyldendal Akademisk.

Hafner-Burton, Emilie M. and Mark A. Pollack (2002): "Mainstreaming Gender in Global Governance”. European Journal of International Relations, 8 (3), 339-373.

Hafner-Burton, Emilie M. and Mark A. Pollack (2009): "Mainstreaming Gender in the European Union: Getting the Incentives Right”. Comparative European Politics, 7 (1), 114-138.

Hedlund, Mary-Ann (2008): “Bevisbyrde”. I Anne Hellum og Kirsten Ketscher (red.): Diskriminerings- og likestillingsrett. Oslo: Universitetsforlaget.

Holst, Cathrine and Anne Elizabeth Stie (2016): "I takt eller utakt? Europeiseringen av Norge.” In Det norske samfunn, edited by Ivar Frønes and Lise Kjølsrød, 270-90. Oslo: Gyldendal Akademisk.

Holst, Cathrine (2018): «Ekspertifisering og europeisering i norske likestillingsutredninger». In: Cathrine Holst, Hege Skjeie and Mari Teigen (eds.), Europeisering av nordisk likestillingspolitikk. Oslo: Gyldendal Akademisk.

Hubert, Agnes et al. (2011): «The European Institute for Gender Equality: a window of oppurtunity for gender equality policies», The European Journal of Women's Studies, $18(2), 169-181$.

Hughes, Melanie M., Pamela Paxton and Mona Lena Krook (2017): “Gender Quotas for Legislatures and Corporate Boards". Annual review of Sociology, 43, 331-352. https://doi.org/10.1146/annurev-soc-060116-053324

Inderhaug, Erle (2018): “En norsk likestillingsreform I EU”. I: Cathrine Holst, Hege Skjeie og Mari Teigen (red.), Europeisering av nordisk likestillingspolitikk. Oslo: Gyldendal Akademisk.

Jacquot, Sophie and Cornelia Woll (2003): "Usage of European Integration-Europeanisation from a Sociological Perspective". European Integration online Papers (EIoP), 7.

Kantola, Johanna (2010): Gender and the European Union. New York: Palgrave Macmillan. Kantola, Johanna and Emmanuela Lombardo (2017): Gender and the Economic Crisis in Europe. New York: Palgrave Macmillan. 
Ketscher, Kirsten (2018): “Uden titel. Diskriminering? Nej Tak!” I: Cathrine Holst, Hege Skjeie og Mari Teigen (red.), Europeisering av nordisk likestillingspolitikk. Oslo: Gyldendal Akademisk.

Kraglund, K. O. (2016): Nødvendig, ønskelig - eller verken eller? En analyse av norske aktørers diskursive bruk av EU i reformprosesser på likestillingsfeltet. Masteroppgave. Institutt for statsvitenskap. Universitetet i Oslo.

Kraglund, Karin O. (2018): "Diskursiv Europeisering. En analyse av fire likestillingspolitiske reformprosesser". I: Cathrine Holst, Hege Skjeie og Mari Teigen (red.), Europeisering av nordisk likestillingspolitikk. Oslo: Gyldendal Akademisk.

Krizsan, Andrea, Hege Skjeie, and Judith Squires, eds. (2012): Institutionalizing Intersectionality? The Changing Nature of European Equality Regimes. Basingstoke: Palgrave Macmillan.

Leira, Arnlaug (2002): Working Parents and the Welfare State: Family Change and Policy Reform in Scandinavia. Cambridge: Cambridge University Press.

Leira, Arnlaug (2012): “Omsorgens institusjoner, Omsorgens kjønn”. In: Ellingsæter, A.L., \& K. Widerberg (eds.). Velferdsstatens familier - Nye sosiologiske perspektiver. Oslo: Gyldendal Akademisk, 76-93.

Lépinard, Eléonore and Ruth Rubio Marin. forthcoming November 2018. Transforming Gender Citizenship: The Irresistible Rise of Gender Quotas in Europe. Cambridge: Cambridge University Press.

Mensi-Klarback, Cathrine Seierstad, and Patricia Gabaldon. 2017. "Setting the Scene: Women on Boards: The Multiple Approaches beyond Quotas." In Cathrine Seierstad, Patricia Gabaldon and Heike Mensi-Klarbach (eds.).Gender Diversity in the Boardroom: Multiple Approaches Beyond Quotas, Volume 2, London: Palgrave Macmillan.

Neyer, Gerda et al. (2017): «EU-policies and fertility: The emergence of fertility-related family policies at the supra-national level”, Families \& Societies

Niskanen, Kirsti (2011): Gender and Power in the Nordic Countries - with focus on politics and business. Oslo: NIKK-publication 2011: 1.

Pollack, Mark A and Emilie Hafner-Burton (2000): "Mainstreaming gender in the European Union”. Journal of European Public Policy, 7 (3), 432-456. https://doi.org/10.1080/13501760050086116

Radaelli, Claudio M. and Romain Pasquier (2006): "Encounters with Europe: Concepts, definitions, and research design”, Politik. 3(9) 
Rees, Teresa (2005): "Reflections on the uneven development of gender mainstreaming in the European Union”. International Feminist Journal of Politics, 7 (4), 555-574. DOI: $10.1080 / 14616740500284532$

Sainsbury, Diane and Christina Bergquist (2009): "The Promise and Pitfalls of Gender Mainstreaming”. International Journal of Feminist Politics, 1 (2), 216-234.

Seierstad, Cathrine, Patricia Gabaldon and Heike Mensi-Klarbach (eds.) 2017. Gender Diversity in the Boardroom: Multiple Approaches Beyond Quotas. London: Palgrave Macmillan.

Skevik, Anne (2003): Family Policies in Norway. NOVA - Norwegian Social Research Skjeie, Hege og Mari Teigen (2003) Menn i mellom. Mannsdominans og likestillingspolitikk. Oslo, Gyldendal Akademisk.

Skjeie, Hege and Mari Teigen (2012): “Duties to promote equality”. In: Lenita Freidenvall and Michelle Micheletti (eds.), Comparisons, Quotas and Critical Change. Stockholm: Stockholm University, 51-61.

Skjeie, Hege (2015) Gender equality and nondiscrimination: how to tackle multiple discrimination effectively?. In: Visions for Gender Equality. European Commission 2015 ISBN 978-92-79-47777-5, 79-82

Skjeie, Hege, Cathrine Holst and Mari Teigen (2017): "Benevolent Contestations: Mainstreaming, Judicialization, and Europeanisation in Norwegian Gender + Equality Debate" In: Heather Mc Rae and Elaine Weiner (eds.), Towards Gendering Institutionalism. Rowman \& Littlefield International, ISBN 9781783489961, 121-144. Solhøy, Stina Hansteen (1999). Politisk vilje møter institusjonell autonomi. Hovedoppgave i statsvitenskap. Oslo: Universitetet i Oslo.

Teigen, Mari and Lena Wängnerud (2009): “Tracing Gender Equality Cultures: Elite Perceptions of Gender Equality in Norway and Sweden”, Politics \& Gender, 5, 21-44. Teigen, Mari (2012): “Gender Quotas in Corporate Boards - On the diffusion of a distinct national policy reform”. In: Fredrik Engelstad \& Mari Teigen (eds.) Firms, Boards and Gender Quotas: Comparative Perspectives. Comparative Social Research, 29. Bingley: Emerald (2012), 115-146.

Teigen, Mari (2015): “The Making of Gender Quotas for Corporate Boards in Norway”. In: Engelstad, Fredrik and Anniken Hagelund (eds.), Cooperation and Conflict the Nordic Way. Work, Welfare and Institutional Change in Scandinavia. De Gruyter Open. 
Terjesen, Siri, Ruth Aguilera, and Ruth Lorenz (2015): “Legislating a Woman's Seat on the Board: Institutional Factors Driving Gender Quotas for Boards of Directors.” Journal of Business Ethics 128 (2), 233-251.

van der Vleuten, Anna (2007): The Price of Gender Equality: Member States and Governance in the European Union. Aldershot: Asgate.

Vollset, Gerd (2011): Familiepolitikkens historie - fra 1970 til 2000. Oslo: Nova.

Walby, Sylvia (2009): Globalisation and Inequalities. London: Sage.

Wladasch, Katrin (2015). The Sanctions Regime in Discrimination Cases and its Effects.

Brussels: Equinet, the European Network of Equality Bodies

\section{Government Reports to Parliament and Government Advisory Commission Reports}

Ot. prp. nr. 77 (2000-2001), Om lov om endringer i likestillingsloven mv.

https://www.regjeringen.no/contentassets/d495493b08ef4fdc9f46412c524f2466/no/pdfa lotp200020010077000dddpdfa.pdf

NOU 2008: 6. Kjønn og lønn. Fakta, analyser og virkemidler for likelønn

https://www.regjeringen.no/contentassets/39b49bdffe6f44faa80f6c3f26de2b8a/no/pdfs/n ou200820080006000dddpdfs.pdf

NOU 2011:18. Struktur for likestilling

https://www.regjeringen.no/contentassets/d0ce229f4f8646afaf4fcaa95d5bb884/no/pdfs/ $\underline{\text { nou201120110018000dddpdfs.pdf }}$

NOU 2012:2. Utenfor og innenfor. Norges avtaler med EU

https://www.regjeringen.no/contentassets/5d3982d042a2472eb1b20639cd8b2341/no/pdf s/nou201220120002000dddpdfs.pdf

NOU 2012:15. Politikk for likestilling

https://www.regjeringen.no/contentassets/dcf92db57c0542c1996b9f821b13ebbe/no/pdfs /nou201220120015000dddpdfs.pdf

NOU 2017: 6 Offentlig støtte til barnefamiliene

https://www.regjeringen.no/contentassets/6ee74831e812490dad20852b7306dc11/no/pdf s/nou201720170006000dddpdfs.pdf 